\title{
Emergomyces canadensis, a Dimorphic Fungus Causing Fatal Systemic Human Disease in North America
}

\section{Ilan S. Schwartz, Stephen Sanche, Nathan P. Wiederhold, Thomas F. Patterson, Lynne Sigler}

We report 4 patients in North America with disease caused by Emergomyces canadensis, a newly proposed species of pathogenic dimorphic fungus. Affected persons were immunocompromised; lived in Saskatchewan, Colorado, and New Mexico; and had systemic disease involving blood, skin, cervix, lung, and lymph node. Two cases were fatal.

$\mathrm{M}$ embers of the recently described fungal genus Emergomyces cause disseminated and often fatal disease in immunocompromised hosts $(1,2)$. So named because of their recent global emergence (1), these dimorphic fungal pathogens have been reported from Africa, Asia, and Europe (3). Here we report from North America 4 cases of invasive fungal disease caused by a novel Emergomyces species, designated Es. canadensis.

\section{The Study}

In 2003, a 39-year-old man with a history of diabetes and a cadaveric renal transplantation 3 years prior visited a hospital in Saskatoon, Saskatchewan, Canada, reporting fever and throat pain. His medications included mycophenolate and prednisone $(25 \mathrm{mg} / \mathrm{d})$. The patient had no history of travel. He kept pet birds, none of which were ill, and had no other animal exposures.

On examination, the patient was cushingoid, normotensive, and afebrile. Results of oropharyngeal, chest, and abdominal examinations were unremarkable. Chest radiograph and computed tomography demonstrated diffuse micronodules, left upper lobe consolidation, and

Author affiliations: Global Health Institute, University of Antwerp,

Antwerp, Belgium (I.S. Schwartz); San Antonio Center for

Medical Mycology, UT Health San Antonio, San Antonio, Texas, USA (I.S. Schwartz, N.P. Wiederhold, T.F. Patterson); University of Saskatchewan, Saskatoon, Saskatchewan, Canada (S. Sanche); UT Health San Antonio Fungus Testing Laboratory, San Antonio (N.P. Wiederhold); South Texas Veterans Health Care System, San Antonio (T.F. Patterson); University of Alberta Biological Sciences, Edmonton, Alberta, Canada (L. Sigler)

DOI: https://doi.org/10.3201/eid2404.171765 mediastinal lymphadenopathy. The patient was assessed by esophagoscopy, which indicated white, dry patches suspicious for esophageal candidiasis; consequently, we started him on oral fluconazole $(200 \mathrm{mg} / \mathrm{d})$. On day 5 postadmission, he had myalgias, arthralgias, and a fever of $38.9^{\circ} \mathrm{C}$, prompting collection of mycobacterial and fungal blood cultures. Two days later, a bronchoscopy demonstrated white patches in the trachea and bronchi. On day 17 of admission, both the blood and bronchoalveolar lavage cultures grew a fungus. Repeated blood cultures subsequently grew the same fungus. We treated the patient with lipid complex amphotericin B for 3 weeks, with clinical improvement, and he was discharged after 7 weeks in the hospital.

Several days later, the patient returned, reporting weakness, postural dizziness, anorexia, and vomiting. Repeated chest radiograph and computed tomography showed patchy consolidation with increased right mediastinal lymphadenopathy. A mediastinoscopy with lymph node biopsy excluded lymphoma. No material was sent for culture, but histopathologic examination with fungal stains demonstrated small, round or oval yeasts (Figure 1). The patient remained afebrile, and he was managed expectantly without additional antifungal therapy. His symptoms resolved, and he was discharged. Serial chest radiographs demonstrated resolution of the mediastinal lymphadenopathy, and no clinical relapse occurred in 3 years of follow-up.

The clinical isolate was referred to the University of Alberta Microfungus Collection and Herbarium (UAMH) for characterization and identification. The fungus grew as a mold phase at $30^{\circ} \mathrm{C}$ and as a yeast at $35^{\circ} \mathrm{C}$ (Figure 2, panels A and B). Microscopic examination of mycelia demonstrated florets of 1 to 3 conidia borne at the ends of slightly swollen conidiophores (Figure 2, panel C), reminiscent of Emmonsia-like fungi $(1,2)$. The yeast cells were small $(2.5-5.0 \mu \mathrm{m})$ and round or oval, with 1 or occasionally 2 narrow-based buds (Figure 2, panel D).

DNA genetic analysis was performed by sequencing the internal transcribed spacer region and D1/D2 domain of the large subunit rDNA as previously described (4). The sequence of the case isolate was identical to one from another clinical isolate obtained in 1992 from another patient in Saskatchewan and thought to represent an 


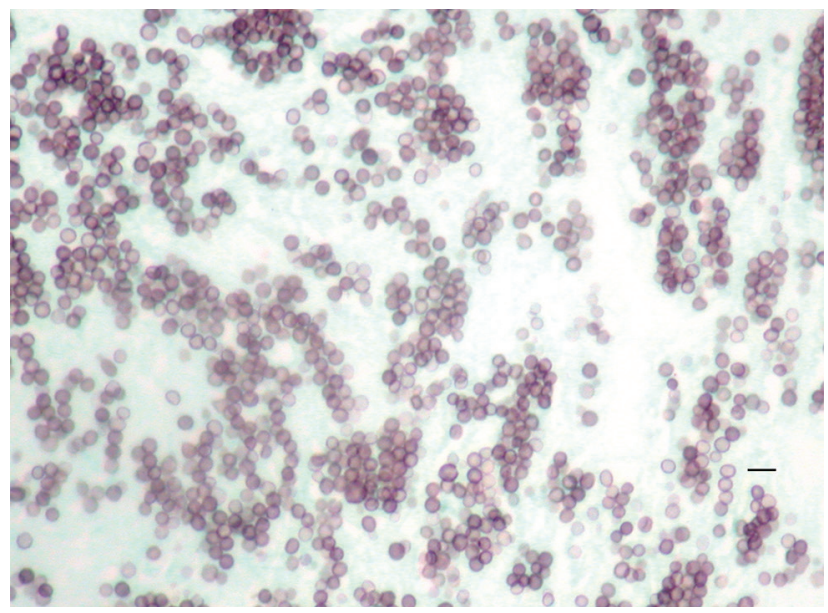

Figure 1. Methenamine silver stain of mediastinal lymph node biopsy, demonstrating small round or oval yeasts in tissue, from a patient infected with novel fungal species Emergomyces canadensis (case-patient 2), Saskatoon, Saskatchewan, Canada, 2003. Scale bar indicates $10 \mu \mathrm{m}$.

undescribed Emmonsia species $(4,5)$. Recent phenotypic and phylogenetic analyses confirmed that these isolates represent a new species within the genus Emergomyces (2); the proposed name is Es. canadensis (Y. Jiang, S. de Hoog, pers. comm., 2018 Jan 19).

We searched for additional clinical isolates among those referred to the Fungus Testing Laboratory at UT
Health San Antonio (San Antonio, TX, USA) during 2001-2016. We reviewed isolates previously identified as Emmonsia species or as Blastomyces dermatitidis based on low-positive ( $<400,000$ relative light units) results on a $B$. dermatitidis DNA probe (AccuProbe, Hologic, Inc., San Diego, CA, USA). We confirmed identification by sequencing of the internal transcribed spacer and $\mathrm{D} 1 / \mathrm{D} 2$ regions and thus identified 2 additional isolates of Es. canadensis.

We compiled and summarized epidemiologic and clinical data from submitting laboratories and clinicians for the 4 clinical Es. canadensis isolates (Table). Two isolates were referred from Saskatchewan, 1 from Colorado, and 1 from New Mexico. All 3 patients for whom medical histories could be ascertained were immunocompromised, 2 with advanced HIV infection and the third with a kidney transplantation. Histopathology results were available for 2 patients: in case 2, small yeasts were observed in tissue from mediastinal lymph node, and in case 3 , in tissue from an endocervical mass. Es. canadensis was cultured from biopsied cutaneous lesions in 2 patients (in cases 1 and 4). For 2 remaining patients, Es. canadensis was cultured from blood, and additionally in 1 patient, from bronchoalveolar fluid. Two patients survived, and 2 died.

We performed limited antifungal susceptibility testing for 2 isolates (6). The MIC of UAMH 10370 was $0.125 \mu \mathrm{g} / \mathrm{mL}$ for amphotericin B. The MIC of UTHSCSA
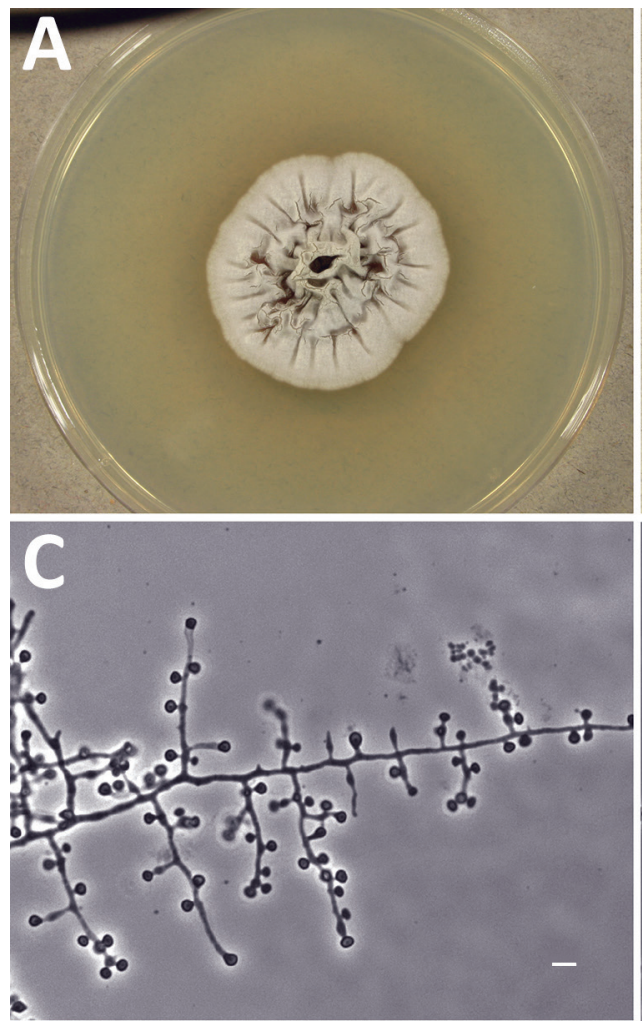

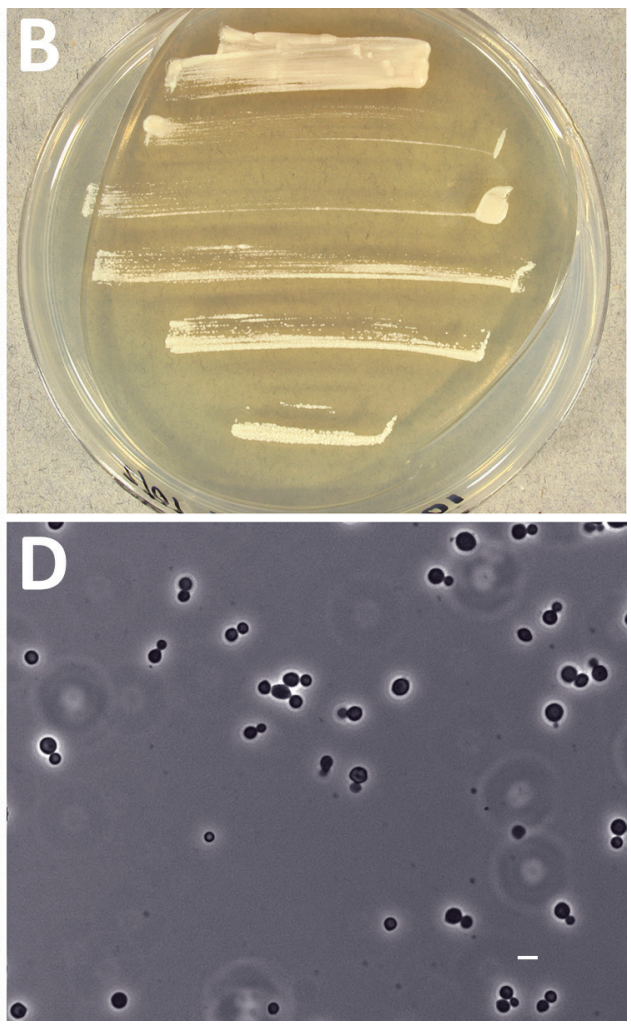

Figure 2. Morphologic features of novel fungal species Emergomyces canadensis isolated from case-patient 2, Saskatoon, Saskatchewan, Canada, 2003. A-B) Colonies grown on potato dextrose agar showing mold phase after 28 days at $30^{\circ} \mathrm{C}(\mathrm{A})$ and yeast phase after 9 days at $35^{\circ} \mathrm{C}(\mathrm{B})$. C) Mycelial phase showing 1-3 conidia borne at the ends of slightly swollen conidiophores or sessile on hyphae. D) Round to oval yeast cells with narrowbased budding produced at $35^{\circ} \mathrm{C}$. Scale bars indicate $5 \mu \mathrm{m}$. 
Table. Epidemiologic and clinical characteristics of 4 patients infected with Emergomyces canadensis, North America, 1992-2015*

\begin{tabular}{|c|c|c|c|c|c|c|c|c|c|}
\hline $\begin{array}{l}\text { Case } \\
\text { no. }\end{array}$ & Year & Location & $\begin{array}{c}\text { Patient } \\
\text { age, y/sex }\end{array}$ & $\begin{array}{l}\text { Medical } \\
\text { history }\end{array}$ & Clinical syndrome & $\begin{array}{l}\text { Specimen } \\
\text { cultured }\end{array}$ & Treatment & Outcome & Strain ID† \\
\hline$\overline{1}$ & 1992 & $\begin{array}{c}\text { Regina, } \\
\text { Saskatchewan }\end{array}$ & $68 / \mathrm{M}$ & HIV & Sepsis, skin lesions & Skin biopsy & - & Died & $\begin{array}{l}\text { UAMH } 7172 \\
\text { (AF038322) }\end{array}$ \\
\hline 2 & 2003 & $\begin{array}{l}\text { Saskatoon, } \\
\text { Saskatchewan }\end{array}$ & $39 / \mathrm{M}$ & $\begin{array}{l}\text { Kidney } \\
\text { transplant, } \\
\text { diabetes }\end{array}$ & $\begin{array}{c}\text { Pneumonia, } \\
\text { tracheitis, } \\
\text { lymphadenopathy, } \\
\text { esophagitis, sepsis }\end{array}$ & $\begin{array}{l}\text { Blood, BAL } \\
\text { fluid }\end{array}$ & $\begin{array}{l}\text { Fluconazole, } \\
\text { then } \\
\text { amphotericin } \\
\text { B }\end{array}$ & Survived & $\begin{array}{l}\text { UAMH } 10370 \\
\text { (EF592151) }\end{array}$ \\
\hline 3 & 2010 & $\begin{array}{l}\text { Colorado } \\
\text { Springs, } \\
\text { Colorado }\end{array}$ & $75 / F$ & - & $\begin{array}{c}\text { Fungemia, } \\
\text { endocervical lesion }\end{array}$ & Blood & - & Died & $\begin{array}{c}\text { UTHSCSA } \\
\text { DI17-85 } \\
\text { (MG777526, } \\
\text { MG777527) }\end{array}$ \\
\hline 4 & 2015 & $\begin{array}{c}\text { Santa Fe, } \\
\text { New Mexico }\end{array}$ & $40 / \mathrm{M}$ & HIV & $\begin{array}{l}\text { Pneumonia, skin } \\
\text { lesions, sepsis }\end{array}$ & Skin biopsy & - & Survived & $\begin{array}{c}\text { UTHSCSA } \\
\text { DI17-84 } \\
\text { (MG777530, } \\
\text { MG777528) }\end{array}$ \\
\hline
\end{tabular}

DI17-85 was $64 \mu \mathrm{g} / \mathrm{mL}$ for fluconazole and $0.125 \mu \mathrm{g} / \mathrm{mL}$ for itraconazole.

\section{Conclusions}

Es. canadensis is one of several newly recognized species within Emergomyces (2), and causes an endemic mycosis in North America, where it should be considered in immunocompromised hosts with systemic disease. Es. africanus causes the most common endemic mycosis in South Africa, primarily affecting HIV-infected persons (7); pulmonary and cutaneous disease are common, and the case-fatality rate is $50 \%(8)$. Invasive disease caused by Es. pasteurianus (previously Emmonsia pasteuriana $[2,9])$ has been reported from Italy, Spain, France, India, China, and South Africa (3). Es. orientalis was reported just once, from a man in China (10). Infection caused by another novel species, Es. europaeus, is known also from a single case from Germany (11).

Limited antifungal susceptibility testing of $2 \mathrm{Es}$. canadensis isolates found MICs elevated for fluconazole and low for itraconazole and amphotericin B. Dukik et al. (12) recently reported antifungal susceptibility results for 2 Es. canadensis isolates including UAMH 7172 (reported as CBS 139872) and UAMH 10370 (reported as CBS 139873). The authors similarly found that MICs were elevated for fluconazole and low for newer triazoles and amphotericin B (12). These findings are consistent with the antifungal susceptibility patterns reported for 50 Es. africanus isolates (7). The anecdotal observation in our study that a patient (in case 2) remained fungemic with Es. canadensis 2 weeks after initiating fluconazole but had rapid clinical improvement with amphotericin $\mathrm{B}$ is consistent with these in vitro results. Pending the availability of further data, treatment of disease caused by Emergomyces spp. infection should follow clinical practice guidelines for the management of other dimorphic fungal infections in immunocompromised hosts (13). Specifically, treatment should include amphotericin B (lipid formulation $3-5 \mathrm{mg} / \mathrm{kg}$ or deoxycholate $0.7-1.0$ $\mathrm{mg} / \mathrm{kg}$ ) for 1-2 weeks, followed by itraconazole (or other newer triazole) for at least 12 months, depending on immune reconstitution (13).

This report raises many questions about the pathogenesis, distribution, and habitat of Es. canadensis. As is the case for other dimorphic fungi, inhalational infection by Emergomyces spp. is presumed to occur, followed by extrapulmonary dissemination and disease in susceptible hosts (3). Although limited by small numbers and the lack of travel histories, these cases suggest that the geographic range of Es. canadensis likely involves central and western regions of North America. An ecologic niche has only been investigated for Es. africanus, which has been detected from various soil habitats and in air samples from Cape Town, South Africa $(14,15)$. Further investigations are required to better understand the epidemiology and prevalence of disease caused by Emergomyces spp. in North America and globally.

\section{Acknowledgments}

The authors acknowledge the laboratory technicians at the Fungus Testing Laboratory and Nancy Wengenack and Amy Gattis for help retrieving clinical data for isolates.

I.S.S. received the support of a Detweiler Travelling Fellowship award from the Royal College of Physicians and Surgeons of Canada.

\section{About the Author}

Dr. Schwartz is an infectious diseases clinician and researcher with interests in emerging fungal infections, immunocompromised hosts, and global health. He is currently a visiting scholar at the San Antonio Center for Medical Mycology at UT Health San Antonio. 


\section{References}

1. Schwartz IS, Kenyon C, Feng P, Govender NP, Dukik K, Sigler L, et al. 50 years of Emmonsia disease in humans: the dramatic emergence of a cluster of novel fungal pathogens. PLoS Pathog. 2015;11:e1005198. http://dx.doi.org/10.1371/journal.ppat.1005198

2. Dukik K, Muñoz JF, Jiang Y, Feng P, Sigler L, Stielow JB, et al. Novel taxa of thermally dimorphic systemic pathogens in the Ajellomycetaceae (Onygenales). Mycoses. 2017;60:296-309. http://dx.doi.org/10.1111/myc.12601

3. Schwartz IS, Maphanga TG, Govender NP. Emergomyces: a new genus of dimorphic fungal pathogens causing disseminated disease among immunocompromised persons globally. Curr Fungal Infect Rep. 2018;12:44-50.

4. Peterson SW, Sigler L. Molecular genetic variation in Emmonsia crescens and Emmonsia parva, etiologic agents of adiaspiromycosis, and their phylogenetic relationship to Blastomyces dermatitidis (Ajellomyces dermatitidis) and other systemic fungal pathogens. J Clin Microbiol. 1998;36:2918-25.

5. Sigler L, Peterson SW. Molecular genetic analysis supports recognition of new species among Emmonsia and Blastomyces isolates. Int J Antimicrob Agents. 2009;34(s2):S93. http://dx.doi.org/10.1016/S0924-8579(09)70427-3

6. Clinical and Laboratory Standards Institute. Reference method for broth dilution antifungal susceptibility testing of filamentous fungi; approved standard, 2nd ed. (M38-A2). Wayne (PA): The Institute; 2008.

7. Maphanga TG, Britz E, Zulu TG, Mpembe RS, Naicker SD, Schwartz IS, et al. In vitro antifungal susceptibility of the yeast and mold phases of the dimorphic fungal pathogen, Emergomyces africanus (formerly Emmonsia sp.), from HIV-infected South African patients. J Clin Microbiol. 2017;55:1812-20. http://dx.doi.org/10.1128/JCM.02524-16

8. Schwartz IS, Govender NP, Corcoran C, Dlamini S, Prozesky H, Burton R, et al. Clinical characteristics, diagnosis, management, and outcomes of disseminated emmonsiosis: a retrospective case series. Clin Infect Dis. 2015;61:1004-12. http://dx.doi.org/10.1093/ $\mathrm{cid} / \mathrm{civ} 439$
9. Gori S, Drouhet E. Cutaneous disseminated mycosis in a patient with AIDS due to a new dimorphic fungus. J Mycol Med. 1998;8:57-63.

10. Wang P, Kenyon C, de Hoog S, Guo L, Fan H, Liu H, et al. A novel dimorphic pathogen, Emergomyces orientalis (Onygenales), agent of disseminated infection. Mycoses. 2017;60:310-9. http://dx.doi.org/10.1111/myc.12583

11. Wellinghausen N, Kern WV, Haase G, Rozdzinski E, Kern P, Marre R, et al. Chronic granulomatous lung infection caused by the dimorphic fungus Emmonsia sp. Int J Med Microbiol. 2003;293:441-5. http://dx.doi.org/10.1078/1438-4221-00281

12. Dukik K, Al-Hatmi AMS, Curfs-Breuker I, Faro D, de Hoog S, Meis JF. Antifungal susceptibility of emerging dimorphic pathogens in the family Ajellomycetaceae. Antimicrob Agents Chemother. 2017;62:e01886-17. http://dx.doi.org/10.1128/ AAC.01886-17

13. Wheat LJ, Freifeld AG, Kleiman MB, Baddley JW, McKinsey DS, Loyd JE, et al.; Infectious Diseases Society of America. Clinical practice guidelines for the management of patients with histoplasmosis: 2007 update by the Infectious Diseases Society of America. Clin Infect Dis. 2007;45:807-25. http://dx.doi.org/ $10.1086 / 521259$

14. Schwartz IS, Lerm B, Hoving JC, Kenyon C, Horsnell WG, Basson WJ, et al. Emergomyces africanus in Soil, South Africa. Emerg Infect Dis. 2018;24:377-80. http://dx.doi.org/10.3201/ eid2402.171351

15. Schwartz IS, McLoud JD, Berman D, Botha A, Lerm B, Colebunders R, et al. Molecular detection of airborne Emergomyces africanus, a thermally dimorphic fungal pathogen, in Cape Town, South Africa. PLoS Negl Trop Dis. 2018; 12:e0006174. http://dx.doi.org/10.1371/ journal.pntd.0006174

Address for correspondence: Ilan S. Schwartz, San Antonio Center for Medical Mycology, UT Health San Antonio, 7703 Floyd Curl Dr, San Antonio, TX 78229, USA; email: ilan.steven.schwartz@gmail.com

\section{Get the content you want delivered to your inbox.}

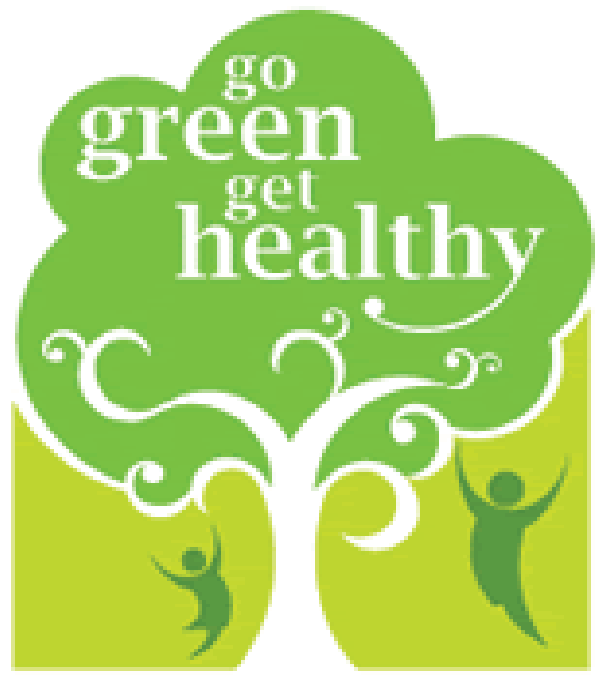

- Table of Contents

- Podcasts

- Ahead of Print articles

- CME

- Specialized Content

\section{Online subscription: wwwnc.cdc.gov/eid/subscribe/htm}

